Economics Series

No. 113, October 2010

Assessing China's Carbon Intensity Pledge for 2020: Stringency and Credibility Issues and Their Implications

ZhongXiang Zhang

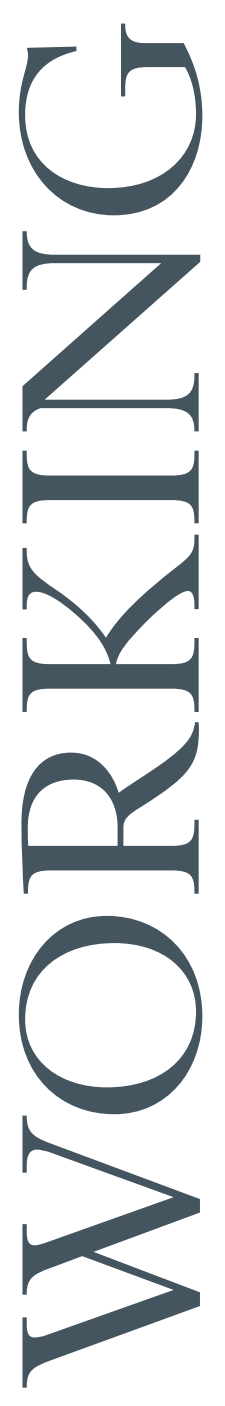

五 
The East-West Center promotes better relations and understanding among the people and nations of the United States, Asia, and the Pacific through cooperative study, research, and dialogue. Established by the U.S. Congress in 1960, the Center serves as a resource for information and analysis on critical issues of common concern, bringing people together to exchange views, build expertise, and develop policy options.

The Center's 21-acre Honolulu campus, adjacent to the University of Hawai'i at Mānoa, is located midway between Asia and the U.S. mainland and features research, residential, and international conference facilities. The Center's Washington, D.C., office focuses on preparing the United States for an era of growing Asia Pacific prominence.

The Center is an independent, public, nonprofit organization with funding from the U.S. government, and additional support provided by private agencies, individuals, foundations, corporations, and governments in the region.

East-West Center Working Papers are circulated for comment and to inform interested colleagues about work in progress at the Center.

For more information about the Center or to order publications, contact:

Publication Sales Office

East-West Center

1601 East-West Road

Honolulu, Hawai‘i 96848-1601

Telephone: 808.944 .7145

Facsimile: 808.944.7376

Email: EWCBooks@EastWestCenter.org

Website: EastWestCenter.org 
들 E A S T - W E S T CEN T E R Collaboration - Expertise * Leadership

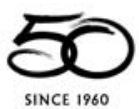

SINCE 1960

\section{Economics Series}

No. 113, October 2010

\section{Assessing China's Carbon Intensity Pledge for 2020: Stringency and Credibility Issues and Their Implications}

\author{
ZhongXiang Zhang
}

ZhongXiang Zhang is a Senior Fellow at the East-West Center. Currently, he is a co-editor of both Environmental Economics and Policy Studies (the official journal of the Society of Environmental Economics and Policy Studies) and International Journal of Ecological Economics and Statistics, and serves on the editorial boards of seven leading international journals and one Chinese journal. Eleven of his publications are cited by IPCC Climate Change 2001: Mitigation and IPCC Climate Change 2007: Mitigation of Climate Change, making him one of the most cited authors in that two extremely comprehensive and authoritative publications on mitigating climate change and the associated costs.

East-West Center Working Papers: Economics Series is an unreviewed and unedited prepublication series reporting on research in progress. The views expressed are those of the author and not necessarily those of the Center. Please direct orders and requests to the East-West Center's Publication Sales Office. The price for Working Papers is $\$ 3.00$ each plus shipping and handling. 


\title{
Assessing China's carbon intensity pledge for 2020: stringency and credibility issues and their implications
}

\author{
ZhongXiang Zhang, Ph.D in Economics \\ 张中祥 美国东西方中心研究部资深研究员、经济学博士 \\ Senior Fellow \\ Research Program \\ East-West Center \\ 1601 East-West Road \\ Honolulu, HI 96848-1601 \\ United States \\ Tel: $+1-808-9447265$ \\ Fax: +1-808-944 7298 \\ Email: ZhangZ@EastWestCenter.org
}

\begin{abstract}
Just prior to the Copenhagen climate summit, China pledged to cut its carbon intensity by $40-45 \%$ by 2020 relative to its 2005 levels to help reach an international climate change agreement at Copenhagen or beyond. This raises the issue of whether such a pledge is ambitious or just represents business as usual. To put China's climate pledge into perspective, this paper examines whether this proposed carbon intensity goal for 2020 is as challenging as the energy-saving goals set in the current $11^{\text {th }}$ five-year economic blueprint, to what extent it drives China's emissions below its projected baseline levels, and whether China will fulfill its part of a coordinated global commitment to stabilize the concentration of greenhouse gas emissions in the atmosphere at the desirable level. Given that China's pledge is in the form of carbon intensity, the paper shows that GDP figures are even more crucial for determining impacts on energy or carbon intensity than are energy consumption and emissions data by examining the revisions of China's GDP figures and energy consumption in recent years. Moreover, the paper emphasizes that China's proposed carbon intensity target not only needs to be seen as ambitious, but more importantly it needs to be credible. Finally, it is concluded with a suggestion that international climate change negotiations need to focus on 2030 as the targeted date to cap the greenhouse gas emissions of the world's two largest emitters in a legally binding global agreement.
\end{abstract}

Keywords: Carbon intensity; Post-Copenhagen climate change negotiations; Climate commitments; China

JEL classification: Q42; Q43; Q48; Q52; Q53; Q54; Q58 


\section{Introduction}

Since launching its open-door policy and economic reforms in late 1978, China has experienced spectacular economic growth, and hundreds of millions of Chinese have been raised out of poverty. In this course, however, China has been heavily dependent on dirty-burning coal to fuel its rapidly growing economy. This has given rise to unprecedented environmental pollution and health risks. On top of these environmental stresses, projected global climate change is expected to pose additional threats to China in the foreseeable future.

Given the fact that China is already the world's largest carbon emitter and its emissions continue to rise rapidly in line with its industrialization and urbanization, China is seen to have greater capacity, capability and responsibility. The country is facing great pressure both inside and outside international climate negotiations to be more ambitious in combating global climate change (Zhang, 2009 and 2010a,b).

Clearly, China, from its own perspective can not afford to and, from an international perspective, is not meant to continue on the conventional path of encouraging economic growth at the expense of the environment. Instead, a range of environmental concerns and pressures has sparked China's determination to improve energy efficiency and to increase the use of clean energy in order to help its transition to a low-carbon economy (Zhang, 2010c).

Improvements in energy efficiency are particularly important in reducing energy consumption and greenhouse gas emissions as they offer win-win options at a relatively low cost compared to other options. China achieved a quadrupling of its GDP with only a doubling of energy consumption between 1980 and 2000 (Zhang, 2003). On the trends of the 1980s and 1990s, the U.S. EIA (2004) estimated that China's $\mathrm{CO}_{2}$ emissions were not expected to catch up with the world's largest carbon emitter until 2030. However, China's energy use had surged since the turn of this century, almost doubling between 2000 and 2007. Despite similar rates of economic growth, the rate of growth in China's energy use during this period (9.74\% per year) has been more than twice that of the previous two decades (4.25\% per year) (National Bureau of Statistics of China, 2009). This change in energy intensity was responsible for an increase of 20 million tons of carbon (MtC) emissions during the period 2001-2007, compared with a reduction of 576 MtC over the period 1980-2000 (Zhang, 2010c). ${ }^{1}$ As a result, China became the world's largest carbon emitter in 2007.

To reverse this trend, China has incorporated for the first time in its five-year economic plan an input indicator as a constraint - requiring that energy use per unit of GDP be cut by $20 \%$ during the $11^{\text {th }}$ five-year period running from 2006 to 2010 (The State Council, 2006). This is widely considered an important step towards building a "harmonious society" through "scientific development". Just prior to the Copenhagen climate summit,

\footnotetext{
${ }^{1}$ See Zhang (1997 and 2000a) for discussion on the methodology to decompose the contributions of inter-fuel switching, energy conservation, economic growth and population expansion to $\mathrm{CO}_{2}$ emissions.
} 
China further pledged to cut its carbon intensity by 40-45\% by 2020 relative to its 2005 levels in order to help to reach an international climate change agreement at Copenhagen or beyond.

This paper focuses on assessing China's proposed climate intensity target for $2020 .^{2}$ To assess whether this target just represents business as usual, the paper first examines whether the proposed carbon intensity goal for 2020 is as challenging as the energysaving goals set in the current $11^{\text {th }}$ five-year economic blueprint, to what extent it drives China's emissions below its projected baseline levels, and whether China does its part as required in order to fulfill a coordinated global commitment to stabilize the concentration of greenhouse gas emissions in the atmosphere at a desirable level. To assess whether the proposed target is quite as ambitious as China argues, the paper next examines the issues of whether it is conservative and whether there is a room for further increase. No doubt, as long as China's pledge is in the form of carbon intensity, the reliability of both emissions and GDP data matters. The paper then addresses reliability issues concerning China's statistics on energy and GDP. Finally, while stressing paramount importance of strict implementation and coordination of the policies and measures enacted to meet China's existing energy-saving goal in 2010, its proposed carbon intensity target in 2020 and whatever climate commitments beyond 2020 that China may take, the paper concludes with a suggestion that international climate change negotiations need to focus on 2030 as the targeted date to cap the greenhouse gas emissions of the world's two largest emitters in a legally binding global agreement.

\section{China's proposed carbon intensity target: ambitious or business as usual?}

Under the Kyoto Protocol, greenhouse gas emissions targets of developed countries are set against their historically observed levels. However, developing countries' standards of living are still very low in comparison with their industrialized counterparts, and they are entitled to further development and economic growth. Thus, unlike developed countries, their emissions targets, if any, must be linked to future, unobserved levels. Moreover, while all countries face economic uncertainties as the recent financial crisis and global economic downturn demonstrate, developing country economies tend to fluctuate more than those of industrialized countries. This will lead to considerable uncertainties over their economic growth rates and thus emissions projections. To mitigate the inherent problems, intensity targets are proposed as a realistic and practical framework for developing country participation (Baumert et al., 1999). This approach is considered appealing to developing countries, in particular those rapidly growing developing countries, because of its distinctive feature of managing the aforementioned economic uncertainties.

\footnotetext{
${ }^{2}$ See Zhang (2000b, 2009 and 2010a,b) for detailed discussion on China's climate
} strategies regarding the format and timeframe that it would take on climate commitments. 
Zhang (2000a,b) envisions that China could make a voluntary commitment to total greenhouse gas emissions per unit of GDP at some point around $2020 .^{3}$ However, it is not until just prior to the Copenhagen climate summit that China pledged to cut its carbon intensity by $40-45 \%$ by 2020 relative its 2005 levels. While this is consistent with China's longstanding opposition to hard emission caps on the ground that such limits will restrict its economic growth, this marks a point of departure from its longstanding position on its own climate actions. Wen Jiabao, China's Prime Minister, made it clear at Copenhagen that China's pledges "are unconditional and they are not dependent on the reduction targets of other nations" (Watts, 2009). Put another way, China will honor its commitments regardless of the outcome of international negotiations. China is working on its $12^{\text {th }}$ five-year economic plan for the period 2011-2015, and the carbon intensity target is expected to be incorporated as a domestic commitment for the first time into China's five-year economic plan.

While some question China's willing action, real discussion has since focused on whether such a pledge is ambitious or just represents business as usual (e.g., Qiu, 2009; Carraro and Tovoni, 2010). China considers it very ambitious, whereas Western scholars (e.g., Levi, 2009) view it just business as usual based largely on the long-term historical trend of China's energy intensity. The issues then arrive: 1) does the proposed target represent business as usual as some Western scholars argue? 2) is the proposed target quite as ambitious as China argues?

Let us start with the first issue. There are several ways to evaluate how challenging this proposed carbon intensity target is. One way is to see whether the proposed carbon intensity goal for 2020 is as challenging as the energy-saving goals set in the current $11^{\text {th }}$ five-year economic blueprint. This involves two issues. One is rational for using energy intensity reduction as a reference. Given the fixed $\mathrm{CO}_{2}$ emissions coefficients of fossil fuels, which convert consumption of fossil fuels into $\mathrm{CO}_{2}$ emissions, and given that China's energy mix is coal-dominated, cutting China's carbon intensity is in fact cutting China's energy intensity, as clearly indicated in Figure 1. So we can use measurable and reported data on energy use in the recent years to infer the stringency of China's proposed carbon intensity target for 2020. Another issue requires the establishment of why the current $20 \%$ energy-saving goal is considered very challenging. China sets a goal of cutting energy use per unit of GDP by $20 \%$ by 2010 relative to its 2005 levels. In 2006, the first year of this energy efficiency drive, while China reversed a rise in its energy intensity in the first half of that year, energy intensity only declined by $1.79 \%$ over the entire year. Although this decline is a first since 2003, it was far short of the targeted $4 \%$. Among the 31 Chinese provinces or equivalent, only Beijing met that energy-saving goal in 2006, cutting its energy use per unit of GDP by $5.25 \%$, followed by Tianjin, another

\footnotetext{
${ }^{3}$ Zhang (2010b) is the expanded version of China country paper that I initially prepared for the United Nations Development Programme project on Promoting Development while Slowing Greenhouse Gas Emissions Growth. When the draft of that China country paper was released, the Washington DC-based Resources for the Future made a press release "Is China Taking Actions to Limit Its Greenhouse Gas Emissions?", 15 September 1998.
} 
metropolitan city in China, with an energy intensity reduction of 3.98\%, Shanghai by $3.71 \%$, Zhejiang by $3.52 \%$ and Jiangsu by $3.50 \%$ (NBS et al., 2007). In 2007, despite concerted efforts towards energy saving, the country cut its energy intensity by $4.04 \%$ (NBS et al., 2009). There were still big variations in energy-saving performance among the 31 Chinese provinces or equivalent. Beijing continued to take the lead, cutting its energy intensity by $6 \%$, followed by Tianjin by $4.9 \%$ and Shanghai by $4.66 \%$ (NBS et al., 2008). This clearly indicated Beijing's commitments to the 2008 Green Olympic Games. In the meantime, however, there were seven provinces whose energy-saving performances were below the national average. 2008 was the first year in which China exceeded the overall annualized target (4.4\%) for energy saving, cutting its energy intensity by $4.59 \%$ (NBS et al., 2009). This was due partly to the economic crisis that reduced overall demand, in particular the demand for energy-intensive products. Overall, the energy intensity was cut by $14.38 \%$ in the first four years of the plan relative to its 2005 levels (Xinhua Net, 2010). In July 2010, China released its energy intensity number for 2009, and its final energy intensity numbers for the years 2005, 2006, 2007 and 2008, which are revised based on the second nationwide economic census. Based on these revised numbers, China's energy intensity fell by 15.61\% from 2006-2009 (NBS et al., 2010). The country would meet its energy-saving goal if it could cut its energy intensity by $4.39 \%$ in 2010 . However, China's energy use rose faster than its economic growth in the first half of 2010, with seven provinces becoming even more energy intensive during this period. This suggests that the country as a whole needs to accomplish the goal set for the whole year only within a half year, with some provinces required to fill even big remaining gaps during this period. Given the annual energy-saving rate of $5.25 \%$ during the period 1980-2000 in which China achieved a quadrupling of its GDP while cutting its energy intensity by about three quarters (Zhang, 2003), achieving such high energysaving rate within a half year poses a significant challenge for the country as well as for those provinces that lagged behind schedule. To achieve the goal, it is widely reported that several provinces issued a strict rotation of rolling blackouts for thousands of factories that required them to shut down five days for every nine they operate. Clearly, the local blackouts are not what the central government intended. While they were not consistent with the national policy and were not rational, it seems that local governments have little choice but to take such irrational measures in such a very short period of time. Moreover, as further discussed in the next section, these reductions in China's energy intensity have already factored in the revisions of China's official GDP data from the second nationwide economic census, part of the government's continuing efforts to improve the quality of its statistics, whose accuracy has been questioned by both the general public inside of China and many analysts both inside and outside of China. Such revisions show that China's economy grew faster and shifted more towards services than the previously estimated, thus benefiting the energy intensity indicator. Even so, it will still not be easy for China to achieve its own set energy-saving goal. If there were no upward revisions of GDP data, it would be impossible at all to meet that target.

All this clearly indicates that picking low-hanging fruit by closing $60.06 \mathrm{GW}$ of small, inefficient coal-fired power plants in the past four years, ahead of the national schedule to decommission $50 \mathrm{GW}$ of smaller and older units in the five years through 2010, helped China to get to where it currently stands (Zhang, 2010a,c). This still leaves a big gap 
between the current overall performance and the 20\% energy-saving goal. However, those low-hanging fruit opportunities can only be captured once. The new carbon intensity target set for 2020 requires an additional $20-25 \%$ on top of the existing target. Achieving this will clearly be even more challenging and costly for China.

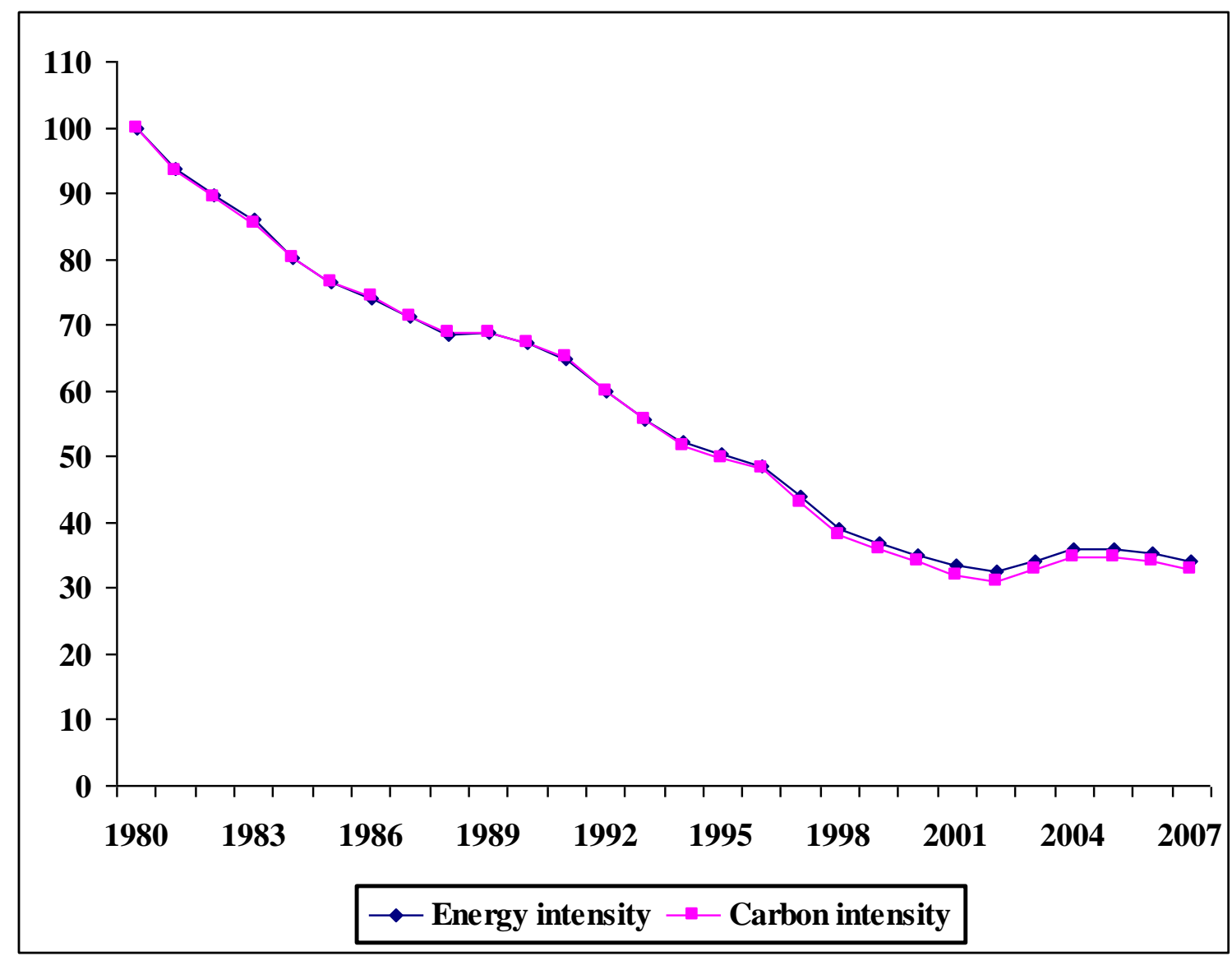

Figure 1 China's Energy Intensity Index and Carbon Intensity Index (1980=100), 1980-2007

Sources: Drawn based on China Statistical Yearbook, various years, and Zhang (1997).

Another way is to assess how substantially this carbon intensity target drives China's emissions below its projected baseline levels, and whether China does its part as required in order to fulfill a coordinated global commitment to stabilize the concentration of greenhouse gas emissions in the atmosphere at the desirable level. The World Energy Outlook (WEO) 2009 (IEA, 2009) has incorporated many policies into the baseline projection that were not incorporated in the WEO 2007 (IEA, 2007). This projection puts China's baseline carbon emissions at $9.6 \mathrm{GtCO}_{2}$ in 2020 . Under the ambitious 450 parts per million (ppm) of $\mathrm{CO}_{2}$ equivalent scenario, China's $\mathrm{CO}_{2}$ emissions are projected to be $8.4 \mathrm{GtCO}_{2}$ by $2020,1.2 \mathrm{GtCO}_{2}$ less than that in the baseline (IEA, 2009). Now let us put China's proposed carbon intensity target into perspective. The calculations of the paper 
show that cutting the carbon intensity by $40-45 \%$ over the period $2006-2020$ would bring reductions of $0.46-1.2 \mathrm{GtCO}_{2}$ in 2020 , which are equivalent to a deviation of $4.8-12.7 \%$ below the WEO 2009 baseline set for China in $2020 .^{4}$ Two key points need to be made. First, even the lower end of that range does not represent business as usual, because it represents a deviation of $4.8 \%$ below the WEO 2009 baseline levels. Second, if China would be able to meet its own proposed $45 \%$ carbon intensity cut, the country would cut emissions of $1.2 \mathrm{GtCO}_{2}$ in 2020 from its baseline levels as is required under the ambitious $450 \mathrm{ppm}$ scenario. That is equivalent to $31.6 \%$ of what the world would need to do in 2020 under the 450 ppm scenario, a share higher than China's share of the world's total $\mathrm{CO}_{2}$ emissions (28\% in 2020). Clearly, the high end of China's target, if met, aligns with the specified obligation that China needs to fulfill under the $450 \mathrm{ppm}$ scenario.

The previous two points clearly show that the proposed carbon intensity target does not just represent BAU as some Western scholars have argued. Now let us see whether the proposed target is quite as ambitious as China argues. This involves assessing the issues of whether it is conservative and whether there is a room for further increase. Arguably, China will claim to meet its carbon intensity target as long as it cuts its carbon intensity by $40 \%$ over the period 2006-2020. This raises the stringency issue of this proposed intensity reduction. IEA (2009) estimates that national policies under consideration in China would bring reductions of about $1 \mathrm{GtCO}_{2}$ in 2020 . This suggests a carbon intensity reduction of $43.6 \%$ in 2020 relative to its 2005 levels, implying that the low end of China's carbon intensity target is conservative. Is there a big deal to emphasize this few percentage differences? It depends really on which country is in question. It may not matter much for a small country, but for China it matters a great deal. Given that China is already the world's largest carbon emitter and its emissions are projected to rise to $28 \%$ of the world's total in 2020 (IEA, 2009), that 3.6\% difference in reductions for China will translate into more than a $10 \%$ difference in reductions for the world as a whole in that year.

Is there a room for China to increase its own proposed carbon intensity reduction of 40$45 \%$ by 2020 ?. It would be hard, but not impossible. Given that many of the policies considered in the WEO 2009 that will cut emissions of $1 \mathrm{GtCO}_{2}$ in 2020 from its baseline levels are not particularly climate-motivated, China could accelerate the speed of, and scale up the implementation, of such policies and enact additional policies with explicit

\footnotetext{
${ }^{4}$ Given China's carbon intensity pledge, baseline matters here, because the extent to which it drives China's emissions below its projected baseline depends on the baseline setting. If those policies under consideration have not been incorporated into the underlying baseline projection, that will lead to higher baseline level than would otherwise have been the case, thus resulting in a higher percentage deviation. This has been illustrated by McKibbin et al. (2010), which assume China's carbon intensity reduction of $26 \%$ under the baseline, much lower than about $40 \%$ under the WEO 2009 baseline (IEA, 2009) and 45\% under the U.S. Energy Information Administration (2009) baseline. As would be expected, McKibbin et al. find that China's carbon intensity pledge amounts to a deviation of $22 \%$ relative to the baseline in 2020 , much higher than that derived from the aforementioned WEO 2009 study.
} 
considerations of climate mitigation and adaptation. This would bring additional reductions in China's carbon intensity.

What then is the yardstick or bound on the energy or carbon intensity of the Chinese economy in 2020? One way is to set it based on China's own medium- and long-term energy conservation plan. Such a plan sets up a quantitative energy-saving target for 2020, and measured in tons of coal equivalent per ten thousand Yuan in 1990 price, it requires China's energy intensity to be cut from 2.68 in 2002 to 1.54 in 2020, with an annual energy saving rate of 3\% between 2003-2020 (NDRC, 2004). This suggests a reduction of China's energy intensity by $42.5 \%$ in 2020 , relative to 2002 levels. With China's rising energy intensity between 2002-2005 as shown in Figure 1, to meet this energy-saving goal under the medium- and long-term energy conservation plan requires China's energy intensity to be cut by more than $42.5 \%$, relative to its 2005 levels. It should be pointed out that this energy-saving plan was set at a time when China faced much less severe environmental stress, energy security concerns and international pressure to take mitigation actions than it is now confronted with. This suggests that China should now aim for an even more ambitious energy-saving goal than it was envisioned under the energy-saving plan set in 2004. Another way is to infer potential level based on historical trend of energy saving. Assuming that China's economy grows at the annual average rate of 7.6\% per year used for the WEO 2009 and that China is able to limit the growth of energy use to half the growth rate of the economy between 2006 and 2020, then China's energy use per unit of GDP would be cut by $42 \%$ by 2020, relative to its 2005 levels. Given China's economic growth over the period 2005-2009, this assumed rate of economic growth is very conservative in China's context. Assuming the more likely growth rate of $8 \%$ per year between 2006 and 2020 and all others remaining unchanged, then China's energy intensity would be cut by $43 \%$ by 2020 , relative to its 2005 levels. This back-of-the-envelope calculation assumes an income elasticity of 0.5 between 2006 and 2020. While China was able to accomplish that during the 1980s and 1990s, going ahead, we should not naturally expect a return to that level, given that China had experienced faster energy consumption growth than economic growth between 2002 and 2005 and, as discussed earlier, is encountering great difficulty meeting its $20 \%$ energy intensity target. Thus, a 42-43\% cut in China's energy intensity by 2020 relative to 2005 levels can be considered as an upper bound on China's energy intensity target. With carbon-free energy meeting 7.1\% of China's total energy needs in 2005 (National Bureau of Statistics of China, 2009) and that share mandated to be increased to 15\%, this $42-43 \%$ cut in energy intensity is equivalent to a 50-51\% cut in carbon intensity between 2006 and 2020, implying that there is a room for China to increase its own proposed carbon intensity reduction of $40-45 \%$ by 2020 . China should therefore aim for a $46-50 \%$ cut in its carbon intensity over the period 2006-2020. The Intergovernmental Panel on Climate Change (IPCC) (2007) recommends developing countries as a group to limit their greenhouse gas emissions to $15-30 \%$ below their baseline levels by 2020 . This $46-50 \%$ carbon intensity reduction will lead to China's emissions reductions of 15-21\% compared with its baseline levels in 2020. That will put China's absolute emissions reductions very much within this IPCC's recommended level. 


\section{Meeting China's carbon intensity: the reliability issue of China's statistics on energy and GDP}

Having an ambitious commitment is one thing. Fulfilling that commitment is another issue. While the level of China's commitments is crucial in affecting the level and ambition of commitments from other countries, it is more important to know whether the claimed reductions in carbon emissions are real. This raises reliability issues concerning China's statistics on energy and GDP.

China is not known for the reliability of its statistics (e.g., Rawski, 2001). China's refusal to budge on U.S. and other industrialized country's demands for greater transparency and checks at Copenhagen was cited by negotiator after negotiator as a key block to reaching a deal (Graham-Harrison, 2009). As long as China's pledges are in the form of carbon intensity, the reliability of both emissions and GDP data matters.

Assuming the fixed $\mathrm{CO}_{2}$ emissions coefficients that convert consumption of fossil fuels into $\mathrm{CO}_{2}$ emissions, the reliability of emissions data depends very much on energy consumption data. Unlike the energy data in the industrial product tables in the China Statistical Yearbook, the statistics on primary energy production and consumption are usually revised in the year after their first appearance. As would be expected, the adjustments made to production statistics are far smaller than those made to consumption statistics, because it is easier to collect information on the relatively small number of energy producers than the large number of energy consumers. Table 1 shows the preliminary and final values for total primary energy consumption and coal consumption in China between 1990 and 2008. Until 1996 revisions of total energy use figures were several times smaller than in the late 1990s and early 2000s. The preliminary figures for total energy use in 1999-2001 were revised upwards by 8-10\%. In all three years, these adjustments were driven by upward revisions of $8-13 \%$ made to the coal consumption figures to reflect the unreported coal production mainly from small, inefficient and highly polluting coal mines. These coal mines were ordered to shut down through a widelypublicized nationwide campaign beginning in 1998, although many had reopened because in many cases local governments had pushed back to preserve local jobs and generate tax revenues as well as personal payoffs. In recent years, preliminary figures for energy use are very close to the final reported ones.

Similarly, China first releases its preliminary GDP figures and then revises them. These revised GDP figures for the years 2005-2008 are further verified based on the second agricultural census released in February 2008 and the second nationwide economic census released in December 2009. With upward revisions of both GDP and the share of services, there is a big variation between the preliminary value for China's energy intensity and the final reported one. As shown in Table 2, such revisions lead to a differential between preliminary and final values as large as $123 \%$ for the energy intensity in 2006. With the government's continuing efforts to improve the quality of China's statistics, there is a downward trend of such a differential as a result of the revisions. 
Table 1 Preliminary and Final Values for Total Primary Energy Consumption and Coal Consumption in China, 1990-2008

\begin{tabular}{lllllll}
\hline Year & \multicolumn{3}{c}{ Total primary energy consumption } & \multicolumn{3}{c}{ Total coal consumption } \\
\cline { 2 - 7 } & $\begin{array}{l}\text { Preliminary } \\
\text { value } \\
\text { (Mtce) }\end{array}$ & $\begin{array}{l}\text { Final } \\
\text { value } \\
\text { (Mtce) }\end{array}$ & $\begin{array}{l}\text { Adjustment } \\
(\%)\end{array}$ & $\begin{array}{l}\text { Preliminary } \\
\text { value } \\
\text { (Mtce) }\end{array}$ & $\begin{array}{l}\text { Final } \\
\text { value } \\
\text { (Mtce) }\end{array}$ & $\begin{array}{l}\text { Adjustment } \\
(\%)\end{array}$ \\
\hline 1990 & 980.00 & 987.03 & 0.7 & 740.88 & 752.12 & 1.5 \\
1991 & 1023.00 & 1037.83 & 1.4 & 777.48 & 789.79 & 1.6 \\
1992 & 1089.00 & 1091.70 & 0.2 & 815.66 & 826.42 & 1.3 \\
1993 & 1117.68 & 1159.93 & 3.8 & 813.67 & 866.47 & 6.5 \\
1994 & 1227.37 & 1227.37 & 0.0 & 920.53 & 920.53 & 0.0 \\
1995 & 1290.00 & 1311.76 & 1.7 & 967.50 & 978.57 & 1.1 \\
1996 & 1388.11 & 1389.48 & 0.1 & 1041.08 & 1037.94 & -0.3 \\
1997 & 1420.00 & 1377.98 & -3.0 & 1043.70 & 988.01 & -5.3 \\
1998 & 1360.00 & 1322.14 & -2.8 & 973.76 & 920.21 & -5.5 \\
1999 & 1220.00 & 1338.31 & 9.7 & 818.62 & 924.77 & 13.0 \\
2000 & 1280.00 & 1385.53 & 8.2 & 857.60 & 939.39 & 9.5 \\
2001 & 1320.00 & 1431.99 & 8.5 & 884.40 & 955.14 & 8.0 \\
2002 & 1480.00 & 1517.97 & 2.6 & 978.28 & 1006.41 & 2.9 \\
2003 & 1678.00 & 1749.90 & 4.3 & 1125.94 & 1196.93 & 6.3 \\
2004 & 1970.00 & 2032.27 & 3.2 & 1333.69 & 1381.94 & 3.6 \\
2005 & 2233.19 & 2246.82 & 0.6 & 1538.67 & 1552.55 & 0.9 \\
2006 & 2462.70 & 2462.70 & 0.0 & 1709.11 & 1709.11 & 0.0 \\
2007 & 2655.83 & 2655.83 & 0.0 & 1845.80 & 1845.80 & 0.0 \\
2008 & $2850.00^{\mathrm{b}}$ & & & $1957.95^{\mathrm{b}}$ & & \\
\hline
\end{tabular}

Notes: Mtce (million tons of coal equivalent).

${ }^{a}$ National Bureau of Statistics of China is expected to adjust both preliminary and final values for energy and coal uses to make all statistics consistent, based on the second nationwide economic census. But such an adjustment in a comparable way will have little effect on a difference between their preliminary and final values.

${ }^{\mathrm{b}}$ Data on energy and coal consumption in 2008 are preliminary value.

Source: Based on China Statistical Yearbook, various years.

From the preceding discussion, it follows that GDP figures are even more crucial to the impacts on the energy or carbon intensity than are energy consumption and emissions data. At Copenhagen, China eventually compromised to agree to open its emissions data to international consultation and analysis. The EU has identified building a robust and transparent emissions and performance accounting framework as a key element of implementing the Copenhagen Accord (European Commission, 2010). How all this will be worked out remains to be seen. China has not agreed to opening its GDP figures to international consultation and analysis. But as long as China's commitments are in the form of carbon intensity, establishing a robust and transparent emissions and performance accounting framework is helpful, but not enough to remove international concern about the reliability of China's commitments. The aforementioned revisions of China's GDP 
figures reflect part of the government's continuing efforts to improve the accuracy and reliability of China's statistics on economic activity. They have nothing to do with the energy intensity indicator, and are certainly not being calculated to make that indicator look good to the government's advantage, although practically they do benefit this indicator. But such revisions have huge implications for meeting China's existing energysaving goal in 2010 and its proposed carbon intensity target in 2020.

Table 2 A Reduction in China's Energy Intensity: Preliminary Value versus Final Value $^{\mathrm{a}}$

\begin{tabular}{|c|c|c|c|c|c|}
\hline Year & $\begin{array}{l}\text { Preliminary } \\
\text { value }(\%)\end{array}$ & $\begin{array}{l}\text { Revised } \\
\text { value }(\%)\end{array}$ & $\begin{array}{l}\text { Re-revised } \\
\text { value }(\%)\end{array}$ & $\begin{array}{l}\text { Final value } \\
(\%)\end{array}$ & $\begin{array}{l}\text { Differential } \\
\text { between } \\
\text { preliminary } \\
\text { and final } \\
\text { values (\%) }\end{array}$ \\
\hline 2006 & $\begin{array}{l}1.23 \\
\text { (March 2007) }\end{array}$ & $\begin{array}{l}1.33 \\
\text { (12 July 2007) }\end{array}$ & $\begin{array}{l}1.79 \\
\text { (14 July 2008) }\end{array}$ & $\begin{array}{l}2.74 \\
\text { (15 July } 2010)\end{array}$ & 122.8 \\
\hline 2007 & $\begin{array}{l}3.27 \\
\text { (March 2008) }\end{array}$ & $\begin{array}{l}3.66 \\
(14 \text { July 2008) }\end{array}$ & $\begin{array}{l}4.04 \\
\text { (30 June 2009) }\end{array}$ & $\begin{array}{l}5.04 \\
\text { (15 July 2010) }\end{array}$ & 54.1 \\
\hline 2008 & $\begin{array}{l}4.59 \\
\text { (30 June 2009) }\end{array}$ & $\begin{array}{l}5.20^{\mathrm{b}} \\
(25 \text { Dec. } 2009)\end{array}$ & & $\begin{array}{l}5.20 \\
(15 \text { July } 2010)\end{array}$ & 13.3 \\
\hline 2009 & $\begin{array}{l}3.98^{\mathrm{c}} \\
(\text { March 2010) }\end{array}$ & $\begin{array}{l}3.23^{\mathrm{d}} \\
(15 \text { July } 2010)\end{array}$ & $\begin{array}{l}3.61 \\
\text { (15 July 2010) }\end{array}$ & & \\
\hline
\end{tabular}

Notes: ${ }^{\text {a }}$ The dates when the corresponding data were released are in parentheses.

b Based on China's revised 2008 GDP from the second nationwide economic census, which raised the growth rate of GDP to $9.6 \%$ from the previously reported $9 \%$ for that year and the share of services in GDP.

c Own calculation based on the National Development and Reform Commission's reporting that China's energy intensity was cut by $14.38 \%$ in the first four years of the $11^{\text {th }}$ five-year plan relative to its 2005 levels (Xinhua Net, 2010).

${ }^{d}$ Own calculation based on China's energy intensity number for 2009, and its final energy intensity numbers for the years 2005 and 2008 (NBS et al., 2010).

Sources: Based on NBS et al. (2007, 2008, 2009 and 2010) and Xinhua Net (2010).

\section{Conclusions}

Concerned about a range of environmental problems and health risks from burning fossil fuels and steeply rising oil imports, China has incorporated for the first time in its fiveyear economic plan an input indicator as a constraint - requiring that energy use per unit of GDP be cut by $20 \%$ during the $11^{\text {th }}$ five-year period running from 2006 to 2010 . Combined with great pressure both inside and outside international climate negotiations to be more ambitious in limiting its greenhouse gas emissions, just prior to the Copenhagen climate summit, China pledged to cut its carbon intensity by $40-45 \%$ by 2020 relative its 2005 levels to help to reach an international climate change agreement at Copenhagen or beyond. This unilateral commitment clearly indicates China's determination to further decouple its energy use and carbon emissions from economic 
growth. The proposed carbon intensity target certainly does not just represent business as usual as some Western scholars have argued. On the other hand, that target may not be quite as ambitious as China argues. Given that China is already the world's largest carbon emitter and its share in the world's total emissions continues to rise, even a few additional percentage reductions in its carbon intensity translate into a significant amount of global emissions reductions. It is hard, but not impossible for China to increase its own proposed carbon intensity reduction target. We suggest that China should aim for a 46-50\% cut in its carbon intensity over the period 2006-2020. That will put China's absolute emissions reductions very much within the IPCC's recommended level for developing countries.

Even if China would raise the target to the level seen as ambitious, that just presents a goodwill of China. It does not necessarily suggest that that target can be met, in particular given that China has to date had limited success in achieving its own $20 \%$ energy-saving goal. Moreover, China has faced great difficulty ensuring that local governments act in accordance with centrally-directed policies. As a common practice, the central government of China sets a national energy intensity goal. This national goal is then decomposed at each province or equivalent. Each province or equivalent further decomposes its energy saving goals at prefecture and county levels. The ability of, and incentives for, lower-level governments to effectively implement energy-saving and pollution-cutting policies are therefore critical, particularly since the last three decades of economic reforms have witnessed a shift in the control over resources and decision making to local governments. As the energy-saving performance of the 31 Chinese provinces or equivalent over the first four years of $11^{\text {th }}$ five-year plan has shown, big variations exist (NBS et al., 2007, 2008, 2009 and 2010). Those provinces or equivalent whose energy-saving performances were below the national average are clearly dragging their feet on meeting the national energy-saving goal. Given that the devolution of decision making to local governments has placed environmental stewardship in the hands of local officials who are more concerned with economic growth, local government's cooperation is crucial to the overall outcomes. To that end, the central government needs to set incentives to get local governments' cooperation. One way to ensure local officials are held accountable for energy saving and pollution cutting in their regions is developing criteria that incorporate energy conservation and environmental performance into the overall evaluation of local officials' performances and applying that criteria consistently to ensure energy saving and pollution cutting in a rational way. Alleviating the financial burden of local governments is another avenue to encourage them not to focus on economic growth alone. The central government really needs to cultivate steady and sizeable sources of revenues for local governments. Enacting property taxes or real estate taxes for local governments is urgently needed. Broadening the current coverage of resource taxation and significantly increasing the levied level would also help to increase the revenues of local governments while conserving resources and preserving the environment. The new resource tax levied on crude oil and natural gas in Xinjiang since 1 June 2010, based on revenues rather than existing extracted volume, is the first step in the right direction.

Clearly, China's proposed carbon intensity target not only needs to be seen as ambitious, but more importantly it needs to be credible, although.some countries seem to prefer to 
encourage China to adopt an ambitious target rather than cautioning it against offering what it might not be able to deliver. Ascertaining this credibility involves two issues. One is whether the claimed carbon emissions reductions themselves are real. This raises reliability issues concerning China's statistics on energy and GDP, given that China is not known for the reliability of its statistics. China's compromise at Copenhagen to agree to open its emissions data to international consultation and analysis is a start, although it remains to be seen how this will work in practice. But as long as China's commitments are in the form of carbon intensity, establishing a robust and transparent emissions and performance accounting framework is helpful, but not enough to remove international concern about the reliability of China's commitments. The revisions of China's GDP figures and energy consumption in recent years show that GDP figures are even more crucial to the impacts on the energy or carbon intensity than are energy consumption and emissions data. While they are certainly not being calculated to make the energy intensity indicator look good to the government's advantage, such revisions have huge implications for meeting China's existing energy-saving goal in 2010 and its proposed carbon intensity target in 2020.

Another issue is whether China is really able to achieve its target, given that China has faced and continues to face great difficulty meeting its own set $20 \%$ energy-saving goal in 2010. Setting the target and enacting the corresponding policies and measures to meet that goal signal the goodwill and determination of China's leaders. To actually achieve the desired outcomes, however, requires strict implementation and coordination of these policies and measures. ${ }^{5}$ China has mostly relied on administrative means to achieve its current $20 \%$ energy-saving goal for 2010 . As discussed in the paper, the country has to date had limited success in meeting that goal. But with rising domestic energy demand and increasing difficulty further cutting energy and carbon intensities, putting a price on carbon is considered a crucial step for China to harness the market to reduce its energy consumption and carbon emissions and genuinely transit into a low-carbon economy. A domestic carbon trading scheme, if established, will serve as a cost-effective supplement to costly administrative means on which China is mainly relying to meet its current energy saving goal. ${ }^{6}$

\footnotetext{
${ }_{6}^{5}$ See Zhang (2010c) for further discussion on these policies and measures.

${ }^{6}$ The key issue is the scope and coverage of that carbon trading scheme. Given the fact that the costs of abating carbon emissions differ significantly among emissions sources cross provinces and sectors, having broad coverage of emissions sources from all industries nationwide creates a means of obtaining low-cost abatement options, thus minimizing the total cost of complying with the national energy-saving and emissions goals. This is an ideal option. In practice, however, a carbon trading in China would have to start from selected sectors or regions, although the limited scope and coverage will reduce its cost-effectiveness, because China needs a reasonable length of time to develop and operate a national carbon market. Take the establishment of an emissions trading scheme as a case in point. Even for the U.S. $\mathrm{SO}_{2}$ Allowance Trading Program, the entire process from the U.S. Environmental Protection Agency beginning to compile the data for its allocation database in 1989 to publishing its final allowance allocations in March 1993 took almost four years. For the first phase of the EU Emissions Trading Scheme,
} 
From the preceding discussion, there is no doubt that achieving this carbon intensity target poses a significant challenge for China. However, even if China would meet that carbon intensity target, it still cannot remove international concern about the reliability of its commitments. As long as China's commitments differ in form from that of the U.S. and other major greenhouse gas emitters, China is constantly confronted with both criticism on its carbon intensity commitment being less stringent and the threats of trade measures whenever the U.S. Senate is shaping its climate bill, given that the inclusion of border measures is widely considered the "price" for passing any U.S. legislation capping its greenhouse gas emissions (Zhang, 2010b). Moreover, the U.S. Senate can always take China as an excuse for its own failure to pass a long-awaited bill to cap U.S. greenhouse gas emissions.

This dilemma is partly attributed to flaws in current international climate negotiations, which have been focused on commitments on the two targeted dates: 2020 and 2050 (Zhang 2010b). However, with the commitment period only up to 2020, there is a very little room left for the U.S. and China, although for reasons very different from each other.

The IPCC calls for cutting global greenhouse gas emissions at least in half by 2050 . To achieve that goal, the IPCC fourth assessment report recommends that global greenhouse gas emissions should peak by 2020 at the latest and then turn downward in order to avoid dangerous climate change consequences, calling for developed countries to cut their greenhouse gas emissions by $25-40 \%$ by 2020 relative to their 1990 levels (IPCC, 2007). This recommendation was incorporated into the Bali Roadmap at the United Nations Climate Summit in 2007. This seems a logical choice. Once the long-term goal (namely target for 2050) is set, one needs a mid-term goal to help facilitate the long-term one. From then, the negotiations on industrialized countries' commitments have been on what emissions reduction targets would be in 2020 .

However, 2020 is just around the corner. More importantly, this date does not accommodate well the world's two largest greenhouse gas emitters, namely the U.S. and China. Because the U.S. withdrew from the Kyoto Protocol, it has not made any substantial preparations to cut emissions as other Kyoto-constrained industrialized countries have done over the past decade. Whether you like it or not, this is a political reality. It is very hard for a unprepared country like the U.S. to take on a substantial emissions cut in 2020 as developing countries have demanded, although it should on a moral ground.

the entire process took almost two years from the EU publishing the Directive establishing a scheme for greenhouse gas emission allowance trading on 23 July 2003 to it approving the last national allocation plan for Greece on 20 June 2005. For developing countries like China with very weak environmental institutions and that do not have dependable data on emissions, fuel uses and outputs for installations, this allocation process is expected to take much longer than what experienced in the U.S. and the EU. The experience suggests that a carbon trading scheme in China is initially of limited scope and coverage. 
In the meantime, China overtook the U.S. to become the world's largest greenhouse gas emitter in 2007, at least twenty years earlier than what was estimated by the U.S. EIA (2004) as late as 2004. The IEA (2009) estimates that about half of the growth of global energy-related $\mathrm{CO}_{2}$ emissions until 2030 will come from China. Combined with huge trade deficit with China, the U.S. has pushed for China to take on emissions caps as early as 2020. Otherwise, the goods from China to U.S. markets will be subject to carbon tariffs. However, as argued in Zhang (2009 and 2010b), the year 2020 is not a realistic date for China to take on the absolute emissions cap, because its carbon emissions would be still on the climbing trajectories beyond 2030, even if some energy saving policies and measures have been factored into such projections. Meanwhile, taking on something for 2050 seems too far away for politicians. If the commitment period were extended to 2030, it would really open up the possibility for the U.S. and China to make the commitments that each wants from the other in the same form, although the scale of reductions would differ from each other. By 2030, the U.S. will be able to commit to much deeper emission cuts that China and other developing countries have demanded, while, as argued in Zhang (2009 and 2010b), China would have approached the threshold to take on the absolute emission cap that the U.S. and other industrialized countries have long asked for.

Being aware of his proposed provisional target in 2020 well below what is internationally expected from the U.S., President Obama announced a provisional target of a $42 \%$ reduction below 2005 levels in 2030 to demonstrate the U.S. continuing commitments and leadership to find a global solution to the threat of climate change. While the U.S. proposed level of emission reductions for 2030 is still not ambitious enough, President Obama inadvertently points to the right direction of international climate negotiations. They need to look at the targeted date of 2030. If international negotiations could lead to much deeper emission cuts for developed countries as well as the absolute emission caps for major developing countries in 2030, that would significantly reduce the legitimacy of the U.S. proposed carbon tariffs and, if implemented, their prospect for withstanding a challenge before WTO. That will also alleviate concern about when China's greenhouse gas emissions peak and what China is going to do in what format. More importantly, it really opens the possibility to cap the greenhouse gas emissions of the world's two largest emitters in a legally binding global agreement.

\section{Acknowledgments}

This paper is built on the invited luncheon speech on Climate Change Policies in the Developing World and the panel discussion on From Architectures to Climate Change Governance at the International Workshop on Climate Change Polices, Presidency of Complutense University, Madrid, Spain, 18-19 February 2010, and was presented at China Update 2010: The Next 20 Years of Reform and Development, Australian National University, Canberra, Australia, 14 July 2010. It has benefited from helpful comments from three anonymous referees. That said, the views expressed here are those of the author. The author bears sole responsibility for any errors and omissions that may remain. 


\section{Reference}

Baumert, K., Bhandari, R. and N. Kete (1999), What Might a Developing Country

Climate Commitment Look Like?, World Resources, Institute, Washington, DC.

Carraro, C. and M. Tavoni (2010), Looking ahead from Copenhagen: How Challenging Is the Chinese Carbon Intensity Target?, VOX, Available at:

http://www.voxeu.org/index.php?q=node/4449.

EIA (2004), International Energy Outlook 2004, U.S. Energy Information Administration (EIA), Washington, DC.

EIA (2009), International Energy Outlook 2009, DOE/EIA-0484(2009), U.S. Energy Information Administration (EIA), Washington, DC, May 27.

European Commission (2010), International Climate Policy post-Copenhagen: Acting Now to Reinvigorate Global Action on Climate Change, COM(2010) 86 final, Brussels, March 9, Available at: http://ec.europa.eu/environment/climat/pdf/com_2010_86.pdf.

Graham-Harrison, E. (2009), Snap Analysis: China Happy with Climate Deal, Image Dented, Reuters, December 18, Available at: http://www.reuters.com/article/idUSTRE5BI0DH20091219.

IEA (2007), World Energy Outlook 2007, International Energy Agency (IEA), Paris.

IEA (2009), World Energy Outlook 2009, International Energy Agency (IEA), Paris.

Intergovernmental Panel on Climate Change (IPCC, 2007), Climate Change 2007:

Mitigation of Climate Change, Working Group III Contribution to the Fourth Assessment Report, Cambridge University Press, Cambridge.

Levi, M. (2009), Assessing China's Carbon Cutting Proposal, Council on Foreign Relations, New York, November 30.

McKibbin, W.J, Morris, A.C. and P.J. Wilcoxen (2010), Comparing Climate

Commitments: A Model-Based Analysis of the Copenhagen Accord, Climate and Energy Economics Discussion Paper, The Brookings Institution, Washington, DC, May 27.

National Bureau of Statistics of China (2009), China Statistical Yearbook 2009, China Statistics Press, Beijing.

National Bureau of Statistic (NBS), National Development and Reform Commission and National Energy Administration (2008), Bulletin on Energy Use per Unit of GDP and other Indicators by Region, Beijing, July 14, Available at: http://www.stats.gov.cn/tjgb/qttjgb/qgqttjgb/t20080714_402491870.htm. 
National Bureau of Statistic (NBS), National Development and Reform Commission and National Energy Administration (2009), Bulletin on Energy Use per Unit of GDP and other Indicators by Region, Beijing, June 30, Available at:

http://www.stats.gov.cn/tjgb/qttjgb/qgqttjgb/t20090630_402568721.htm.

National Bureau of Statistic (NBS), National Development and Reform Commission and National Energy Administration (2010), Bulletin on Energy Use per Unit of GDP and other Indicators by Region, Beijing, August 3, Available at: http://www.stats.gov.cn/tjgb/qttjgb/qgqttjgb/t20100803_402662765.htm.

National Bureau of Statistic (NBS), National Development and Reform Commission and Office of The National Energy Leading Group (2007), Bulletin on Energy Use per Unit of GDP and other Indicators by Region, Beijing, July 12, Available at: http://hzs.ndrc.gov.cn/newjn/t20070809_152873.htm.

National Development and Reform Commission (NDRC, 2004), China's Medium- and Long-term Plan for Energy Conservation, Beijing, November, Available at: http://www.sdpc.gov.cn/xwfb/W020050707568608679047.doc.

Qiu, J. (2009), China's Climate Target: Is It Achievable?, Nature, Vol. 462, pp. 550-551.

Rawski, T.G. (2001), What Is Happening to China's GDP Statistics?, China Economic Review, Vol. 12, No. 4, pp. 347-354.

The State Council (2006), The Outline of the Eleventh Five-year Plan for National Economic and Social Development of The People's Republic of China, China Network, Beijing, March 16, Available at: http://www.gov.cn/ztzl/2006-03/16/content_228841.htm.

Watts, J. (2009), China 'Will Honour Commitments' Regardless of Copenhagen Outcome, The Guardian, December 18, Available at: http://www.guardian.co.uk/environment/2009/dec/18/china-wen-jiabao-copenhagen.

Xinhua Net (2010), NDRC: The $11^{\text {th }}$ Five-Year Pollution-Cutting Goals Met Ahead of the Schedule, March 10, Available at: http://news.sina.com.cn/c/2010-0310/152019834186.shtml.

Zhang, Z.X. (1997), The Economics of Energy Policy in China: Implications for Global Climate Change, New Horizons in Environmental Economics Series, Edward Elgar.

Zhang, Z.X. (2000a), Decoupling China's Carbon Emissions Increases from Economic Growth: An Economic Analysis and Policy Implications, World Development, Vol. 28, No. 4, pp. 739-752.

Zhang, Z.X. (2000b), Can China Afford to Commit itself an Emissions Cap? An Economic and Political Analysis, Energy Economics, Vol. 22, No. 6, pp. 587-614. 
Zhang, Z.X. (2003), Why Did the Energy Intensity Fall in China's Industrial Sector in the 1990s?, The Relative Importance of Structural Change and Intensity Change, Energy

Economics, Vol. 25, No. 6, pp. 625-638.

Zhang, Z.X. (2009), In What Format and under What Timeframe Would China Take on Climate Commitments? A Roadmap to 2050, International Environmental Agreements:

Politics, Law and Economics, forthcoming, Available at: http://www.feem.it/userfiles/attach/20109201035374NDL2010-112.pdf.

Zhang, Z.X. (2010a), Is It Fair to Treat China a Christmas Tree to Hang Everybody's Complaints? Putting its Own Energy-Saving into Perspective, Energy Economics, Vol. 32, Special Issue on Asian Energy in the Context of Growing Security and Environmental Concerns, pp. S47-S56.

Zhang, Z.X. (2010b), The U.S. Proposed Carbon Tariffs, WTO Scrutiny and China's Responses, International Economics and Economic Policy, Vol. 7, Nos. 2-3, pp. 203-225.

Zhang, Z.X. (2010c), China in the Transition to a Low-Carbon Economy, Energy Policy, Vol. 38, pp. 6638-6653. 